Sugden, B. (1953). J. gen. Microbiol. 9, 44-53.

\title{
The Cultivation and Metabolism of Oligotrich Protozoa from the Sheep's Rumen
}

\author{
BY BRENDA SUGDEN \\ The Rowett Research Institute, Bucksburn, Aberdeenshire
}

\begin{abstract}
SUMMARY: Suspensions of the oligotrich protozoan, Metadinium medium, were extracted from whole rumen contents by allowing the large protozoa to settle out from the bulk of the rumen liquor and concentrating by pouring off the supernatant. The settled protozoa were separated from the associated rumen debris by incubation with maltose, when a bacterial fermentation set in with a vigorous production of gas which carried most of the rumen debris to the surface for removal by gentle suction. After repeated washing of the protozoa by resuspension in buffer and removal of the supernatant, $M$. medium was cultivated on powdered cotton-wool $(0.05 \%)$ and powdered hay $(0.05 \%)$ in buffer at $\mathbf{p H ~} 6.8$. These oligotrich protozoa remained alive and dividing for 12 days. A species of Entodinium, concentrated from rumen liquor and washed by centrifugation, after the larger protozoa had settled out, was kept alive for 12-14 days under similar conditions in the presence of rice starch grains instead of powdered cotton-wool. Streptomycin $(560 \mu \mathrm{g} . / \mathrm{ml}$.) was used to prepare cultures of protozoa which were bacteriologically sterile when tested by streaking agar plates containing yeast extract, starch and glucose or cellobiose. Under these conditions, Entodinium spp. disappeared within $24 \mathrm{hr}$. and $M$. medium in 3 or 4 days. This suggests that these organisms are dependent on bacteria for some of their metabolic processes. It is concluded that the species of Metadinium studied here contained symbiotic cellulolytic bacteria which were destroyed by streptomycin, but that the protozoa continued at least for some time to draw on their polysaccharide reserves after treatment with the antibiotic. Rumen oligotrichs may be of use to the sheep by acting as 'reservoirs' of polysaccharide and so preventing rapid bacterial breakdown. The relationship between the protozoa and the ruminant is considered to be a true symbiosis.
\end{abstract}

There are several records of attempts to cultivate oligotrich protozoa of the rumen contents of ruminants; the most successful attempts were those of Hungate $(1942,1943)$ in which he kept alive certain Eudiplodinium species for a year and more. Earlier attempts by Knoth (1928), Margolin (1930), and Westphal (1934) met only with very limited success. In the present work, Hungate's technique (1942) was followed quite closely but with different species of oligotrichs. The species were identified from Dogiel's monograph (1927) and Bhatia (1936; taken from Kofoid \& MacLennan, 1932). Antibiotics have been widely used as a means of preparing bacteria-free protozoa but with emphasis on the preparation of cultures of flagellate protozoa. The aerobic ciliate, Tetrahymena geleii (now called $T$. pyriformis), survived treatment with 1000 units streptomycin/ml. (Phelps, 1947); but d'Agostino Barbaro (1951) reported that certain rumen ciliates were killed within $6 \mathrm{hr}$. by concentrations of streptomycin as low as $400 \mathrm{units} / \mathrm{ml}$. She made no observations on the resistance of individual species.

In a previous publication Sugden $\&$ Oxford (1952) presented results on the 


\section{Culture and metabolism of rumen oligotrichs}

cultivation and metabolism of holotrichs from the rumen of sheep. In the present paper investigations into the metabolism of certain species of rumen oligotrichs are reported, with experiments to find how dependent they are on bacteria for their digestive processes.

\section{METHODS}

The rumen material was obtained from two sheep, nos. 272 and 879 , fed on a hay diet, and sheep 8060 fed on a diet of hay and dried grass (for the history of these animals see Oxford, 1951; Sugden \& Oxford, 1952). The rumen liquor used was extracted through permanent rumen fistulae, as described previously (Oxford, 1951). After removing the larger fragments of plant material by straining through surgical gauze, the liquor was left to stand in an incubator at $38^{\circ}$ for 1-2 hr.; the settled deposit then contained most of the larger protozoa; the small protozoa, e.g. Entodinium spp., remained in suspension. The mode of separation of the protozoa after this stage depended on the species required.

\section{Preparation of suspensions of Metadinium medium}

The large protozoa, including $M$. medium, usually settled out of the rumen liquor and were concentrated by pouring off the supernatant. It was not possible to use a preliminary glucose fermentation as in the preparation of holotrichs (Heald, Oxford \& Sugden, 1952), since the large oligotrichs do not give a rapid response to any added substrate. When, however, the protozoa from $1000 \mathrm{ml}$. of rumen liquor were concentrated to $250 \mathrm{ml}$. and incubated with 3 g. maltose, a bacterial fermentation set in which caused a vigorous production of gas which carried most of the rumen debris to the surface. When holotrichs also were present initially it was found better to use maltose, a substrate not utilized by holotrichs (Masson \& Oxford, 1951). Gentle suction was used to draw off the top layer of rumen material, and much of the supernatant liquid without disturbing the settled protozoa. The liquid drawn off was replaced by warmed buffer and the incubation continued for a further $45 \mathrm{~min}$. before the procedure was repeated. Fermentation and washing were carried out in a $250 \mathrm{ml}$. conical flask fitted with a rubber stopper and bunsen valve; before replacing this stopper, the air in the top of the flask was displaced by $\mathrm{CO}_{2}$. After a second wash with buffer, a relatively clean suspension of $M$. medium and holotrichs was left which was concentrated to $100 \mathrm{ml}$. for inoculation into four culture flasks. This inoculum contained only $M$. medium when the sample was taken from sheep 8060, the rumen of which at the time of the experiment was holotrich-free. This was the preferred inoculum, although when holotrichs were present they did not survive long on the substrates provided.

\section{Suspensions of Entodinium species}

Organisms of species of Entodinium remained in suspension with bacteria in the original rumen liquor and could only be separated from the bacteria with difficulty. By repeated centrifugation a relatively good separation was 
effected but this also exposed the protozoa to excessive aeration and cooling; a single centrifugation in $100 \mathrm{ml}$. tubes at 500-700 r.p.m. for 2 min. was therefore used. This gave satisfactory results in that organisms of the Entodinium spp. were concentrated into a small volume and many of the contaminating bacteria were removed.

\section{Method of cultivation}

For cultivation and tests of inhibition by streptomycin, $100 \mathrm{ml}$. conical flasks, fitted with rubber stoppers and bunsen valves, were used. The inorganic buffer for all washing and cultivation purposes was similar to that described by Sugden \& Oxford (1952) for holotrich culture, although precautions were taken to keep it more anaerobic. The composition of the medium was (in \%, w/v): $\mathrm{NaCl}, 0.5 ; \mathrm{CH}_{3} \mathrm{CO}_{2} \mathrm{Na}, 0.15 ; \mathrm{K}_{2} \mathrm{HPO}_{4}, 0.1 ; \mathrm{KH}_{2} \mathrm{PO}_{4}, 0.03 ; \mathrm{CaCl}_{2} .6 \mathrm{H}_{2} \mathrm{O}$, $0.01 ; \mathrm{MgSO}_{4} .7 \mathrm{H}_{2} \mathrm{O}, 0.01$. This solution was autoclaved at $15 \mathrm{lb}$./sq.in. for 10 min., cooled to $38^{\circ}$, and then a mixture of $95 \%$ nitrogen $+5 \%$ carbon dioxide was passed through it for $5 \mathrm{~min}$., by means of a sterile Pasteur pipette containing a long plug of cotton-wool. (The efficiency of this technique was tested by bubbling some of this gas mixture for 5 min. into Wright's nutrient broth; no bacteria developed after several days' incubation at $\mathbf{3 8}^{\circ}$.) Sterile sodium sulphide to give a final concentration of $0.01 \%(w / v)$ in the buffer was added to improve the reducing conditions (Hungate, 1950). The final pH value of the buffer was 6.8 ; its $\mathrm{pH}$ value was stable and it remained sterile for several days when kept at $38^{\circ}$.

The substrates, in weighed amounts suitable for addition to the cultures each day, were sterilized in $5 \times \frac{1}{2} \mathrm{~cm}$. Durham tubes at $140^{\circ}$ for $1 \mathrm{hr}$. For the cultivation of $\boldsymbol{M}$. medium the buffer medium contained substrate, $0.05 \%$ $(\mathrm{w} / \mathrm{v})$ powdered cotton-wool and $0.05 \%(\mathrm{w} / \mathrm{v})$ powdered hay, added daily. The powdered cotton-wool was prepared by cutting up ordinary absorbent cotton-wool with small scissors or by soaking it in conc. $\mathrm{HCl}$ for $48 \mathrm{hr}$. at room temperature, and washing, drying and then grinding it for $2 \mathrm{hr}$. in a ball mill (cf. Hungate, 1950). For the cultivation of Entodinium spp. rice starch (0.05\%, $\mathrm{w} / \mathrm{v})$ and powdered hay $(0.05 \%, \mathrm{w} / \mathrm{v})$ were added.

The original inoculum for a $100 \mathrm{ml}$. culture flask containing $75 \mathrm{ml}$. of medium was $25 \mathrm{ml}$. of concentrated protozoa. To the medium was added the appropriate substrate. Before finally closing the flask, $\mathrm{CO}_{2}$ was bubbled in to displace the small volume of air in the neck of the flask. The cultures were incubated at $38^{\circ}$ and the buffer and substrate were replaced daily. The $\mathrm{pH}$ value of the cultures remained stable and rarely fell below $6 \cdot 0$.

\section{Nitrogenous supplements}

Trials were made with various sources of organic nitrogen; powdered hay was finally selected. Rumen liquor, lightly spun down to remove protozoa, was added at $10 \%(\mathrm{v} / \mathrm{v})$ but had no definite stimulatory effect even when freshly removed from the sheep. Rumen liquor, freed from bacteria by centrifugation and Seitz filtration, as used for holotrich cultures (Sugden \& Oxford, 1952) was likewise ineffective. Various preparations of grass juice, 
reported by Sugden \& Oxford (1952) to improve the growth of holotrichs, were tried in the presence of powdered cellulose for oligotrich cultures. In no culture did $0.1 \%(\mathrm{v} / \mathrm{v})$ or $0.5 \%(\mathrm{v} / \mathrm{v})$ grass juice (deproteinized by boiling) or $0.1 \%(\mathrm{w} / \mathrm{v})$ of the ethanol precipitate from boiled grass juice maintain $M$. medium for longer than 8 days, which period of time was easily surpassed by a supplement of powdered hay (see later).

\section{The use of antibiotics}

Streptomycin was selected from a number of antibiotics tested (which included penicillin, aureomycin and chloramphenicol) as being the only antibiotic which suppressed at least certain of the rumen bacteria without being toxic to the oligotrich protozoa. The following concentrations (mM) of streptomycin were tested: $0 \cdot 1,0.2,0.4,0.6,0.8$ and $1.0 ; 0.8 \mathrm{~mm}$ streptomycin (i.e. $560 \mu \mathrm{g} . / \mathrm{ml}$.) was finally used. $8 \mathrm{ml}$. of a $10 \mathrm{mM}$ stock solution of streptomycin in sterile water were added to the culture flasks containing $100 \mathrm{ml}$. medium as required.

\section{Tests for absence of bacteria}

Tests for the absence of bacteria from the cultures were made by streaking on agar plates. The agar medium had the following composition: Difco yeast extract, $1 \%$; Bacto-tryptose, $1 \%$; $\mathrm{K}_{2} \mathrm{HPO}_{4}, 0.1 \%$; agar, $2 \%$; starch, $0.6 \%$; glucose, $0.5 \%$. Sometimes cellobiose, $0.5 \%$, replaced glucose but this did not alter the results. The plates were usually incubated aerobically at $38^{\circ}$; incubation under anaerobic conditions did not bring up a different growth. The sheep rumen has normally a large facultatively anaerobic bacterial population (MacPherson, 1953). When tests were made for bacteria within cells of $\boldsymbol{M}$. medium, deep cultures in agar medium in test-tubes were used. The agar medium, $10 \mathrm{ml}$./tube, was kept in a water-bath at $45^{\circ}$ before inoculation. Individual protozoa were removed from the culture flasks and taken through four washes of sterile buffer before six organisms were added to each tube of agar medium; these were incubated at $38^{\circ}$ for $48 \mathrm{hr}$.

\section{RESULTS}

\section{Cultivation and metabolism of Metadinium medium}

When clean finely powdered cellulose was added to cultures containing M. medium, the organisms immediately ingested large quantities of it (P1. 1, fig. 1). There was no rapid gas and acid formation similar to that produced by rumen holotrichs in the presence of a glucose substrate (Heald \& Oxford, 1953), although within $1 \mathrm{hr}$. M. medium stained more heavily with Lugol's iodine than it did initially. The ingested cellulose fibres were seen to disintegrate slowly within the cells, and were finally stored as starch grains, 5-10 $\mu$. in diameter, first in the skeletal plates and then around the periphery in the ectoplasm (see later). No chemical investigation of this starch has yet been made; but from the size, shape and iodine-staining properties of the granules, it appears to be identical with that of the holotrichs, i.e. it is amylopectin-like 
in composition and free from amylose. A specimen is now in the hands of the Edinburgh University Chemistry Department for further study.

When the cotton-wool was not as finely powdered its breakdown to storage starch was considerably slower. The possibility that cellulose prepared by hydrochloric acid treatment was degraded and so made more readily digestible was investigated. Parallel experiments were set up to compare the behaviour of untreated absorbent cotton-wool which had simply been cut up with scissors with that of acid-treated cotton-wool which had been ground in a mortar to particles of similar size. There was no difference in the two cultures to which powdered hay was not added; both lived for 5 days only (Table 1). In the presence of powdered cotton-wool + powdered hay, these cultures of $\boldsymbol{M}$. medium regularly survived for 12 days, showing frequent division up to the eighth day, but after this the numbers dwindled. It appeared that the hay acted as a source of organic nitrogen; the cells were never seen to ingest anything particulate except powdered cotton-wool. Rice and potato starch grains were also utilized by the $\boldsymbol{M}$. medium organisms but were not as effective as cellulose. The results of the attempts to cultivate $M$. medium, using various nitrogenous supplements, are summarized in Table 1.

Table 1. Results of culture trials with Metadinium medium

Carbohydrate substrate (50 mg. per day)

No substrate

Powdered cotton-wool

Hand-cut cotton-wool

Finely-powdered cotton-wool

Finely-powdered cotton-wool

Finely-powdered cotton-wool

Finely-powdered cotton-wool

$\begin{array}{cc}\begin{array}{c}\text { Organic nitrogen } \\ \text { supplement } \\ \text { (per day) }\end{array} & \begin{array}{c}\text { Length of life } \\ \text { of culture } \\ \text { (days) }\end{array} \\ 0 & 1 \\ 0 & 5 \\ 0 & 5 \\ \text { Rumen liquor (10 ml.) } & 5 \\ \text { Grass juice (0.5 ml.) } & 8 \\ \text { Hay (50 mg.) } & 12 \\ \text { Hay (50 mg.)+rumen } & 10 \\ \text { liquor (10 ml.) } & \end{array}$

Quantitative determination of residual cellulose by the standard Crampton \& Maynard (1938) method have consistently shown a half to two-thirds utilization of substrate over 2 to 4-day periods when powdered cotton-wool was the only source of cellulose. It is not claimed that these cultures of M. medium were completely free from bacteria, but that the number of bacteria present was too small to account for the rapid disappearance of cellulose, which amounted to $150-200 \mathrm{mg}$. Furthermore, no source of organic nitrogen was included in the medium, and without this, thriving cultures of cellulolytic bacteria would not develop (Hungate, 1950).

\section{Cultivation and metabolism of Entodinium species}

Organisms of Entodinium spp. were kept alive for 12-14 days under conditions similar to those used for the cultivation of $M$. medium, except that the carbohydrate used was rice starch instead of cellulose. The original inoculum (PI. 1, fig. 2) usually contained as many as four species of Entodinium (i.e. E. longinucleatum Dogiel; E. caudatum Stein; E. simplex Dogiel; 
$E$. nanellum Dogiel), but the population changed during cultivation in vitro. Neither of the smaller species ( $E$. simplex and $E$. nanellum) ingested starch grains, and they often died out within a few days, presumably because the original rumen bacteria on which they fed had disappeared or had been replaced by species which were not as suitable. From about the seventh day onwards only one species survived; this organism most closely resembled Dogiel's $E$. longinucleatum except that his was slightly smaller. The organism in our cultures always stained positively with Lugol's iodine both for storage and ingested starch, and continued to divide until the death of the culture. The sudden death of these cultures after 14 days may have been due to the final disappearance of some essential component of the original rumen inoculum, but this possibility appears to be discounted by the lack of effect of adding fresh protozoa-free rumen liquor daily. Another possibility is the accumulation of a toxic waste product from the protozoa. The site of breakdown of starch grains in the organisms of Entodinium spp. is the central endoplasmic area known as the 'gastric sac' (see Mangold, 1929). Disintegration of the starch grains takes place here, after which the soluble products are transported and stored as small polysaccharide granules in the periphery of the cell (P1. 1, fig. 3).

\section{Effect of streptomycin on Metadinium and Entodinium spp.}

The effect of streptomycin was tested by setting up cultures as described above, with the addition of streptomycin to a final concentration of $560 \mu \mathrm{g} . / \mathrm{ml}$. When replacing the medium $24 \mathrm{hr}$. later, a similar quantity of streptomycin was again included. Tests by streaking on nutrient agar plates, incubated aerobically or anaerobically, showed that this concentration of streptomycin usually inhibited all the rumen bacteria which might have grown on this medium, without unduly harming the protozoa. It was considered likely that most rumen bacteria would grow on this agar medium.

The possibility was tested of streptomycin being transferred to the agar plate in sufficient quantities to inhibit the growth of bacteria in the inoculum. One loopful of $0.8 \mathrm{mM}$ streptomycin in sterile buffer was streaked on half the agar plate and an active $18 \mathrm{hr}$. culture of an intestinal streptococcus known to be sensitive to streptomycin was immediately streaked on to the same places. On the other half of the plate, the streptococcus alone was streaked. After incubation at $38^{\circ}$ for $24 \mathrm{hr}$., the streptococcus had grown equally well on both halves of the plate. Thus it is safe to assume that there is no inhibition of growth due to a 'carry-over' of streptomycin on to the plate.

Cultures of $M$. medium were easily made free from those bacteria which were capable of growth on the test medium, but unlike the holotrichs (Heald et al. 1952), they became fewer and less active after 3 or 4 days; the control cultures lived up to 12 days. $M$. medium did not store starch as effectively after streptomycin treatment, whether the substrate supplied was cellulose or rice starch grains. Presumably the cells drew on their carbohydrate reserves for the short time they survived after treatment. The storage 'starch' stainable with iodine certainly dwindled. 
When single cells of $\boldsymbol{M}$. medium were washed and incubated in deep cultures of nutrient agar, those from streptomycin-treated cultures showed no bacterial growth whether the agar medium contained glucose or cellobiose. Pl. 1, fig. 4, shows the effect of incubating agar deep cultures made from control and streptomycin-treated cultures for $48 \mathrm{hr}$. at $38^{\circ}$. Similar results were obtained by incubating holotrich protozoa in agar deep cultures.

After two treatments with streptomycin $(560 \mu \mathrm{g} . / \mathrm{ml}$.$) , when the agar test$ plates showed no growth of bacteria, the Entodinium spp. invariably died out. This indicated that Entodinium spp. were in all probability dependent on the presence of bacteria. Death of the Entodinium spp. was not due to a direct toxic effect of streptomycin on the protozoa, because in two experiments when resistant strains of bacteria developed $\boldsymbol{E}$. longinucleatum lived on for the usual 12 days.

\section{DISCUSSION}

The concentration of streptomycin $(560 \mu \mathrm{g} . / \mathrm{ml}$.) used should have a rapidly bactericidal effect on most bacteria, although it is not possible to say with certainty, on all bacteria. This concentration is over twenty times the dose required for the rapid killing of Bacterium coli according to Pulvertaft (1952). Furthermore, according to Umbreit (private communication), there is as yet no certain instance of a naturally-occurring bacterium, which has never previously been in contact with streptomycin, being initially resistant to that antibiotic. In this present work, the high concentration of streptomycin was used to prevent the development of resistant strains of bacteria. Heald et al. (1952) showed that when thick suspensions of young cultures of Bact. coli and a starch-fermenting rumen streptococcus were added to washed suspensions of rumen holotrich protozoa just before the first dose of streptomycin (560 $\mu \mathrm{g} . / \mathrm{ml}$.), the bacteria were completely killed within $24-48 \mathrm{hr}$.

According to Wasserman, Duncan, Churchill \& Huffman (1952), $25 \mu \mathrm{g}$. streptomycin $/ \mathrm{ml}$. is sufficient to inhibit cellulose breakdown by mixed rumen contents, probably consisting mostly of bacteria. There are no known records of tests for the effect of streptomycin on pure cultures of rumen cellulolytic bacteria; such pure cultures are difficult to isolate (Hungate, 1950). In view of the known properties of streptomycin (see above), it is justifiable to assume that the very high concentration $(560 \mu \mathrm{g} . / \mathrm{ml}$.) used was likely to inhibit all such rumen bacteria, as the tests by Wasserman et al. (1952) showed.

Rumen holotrich protozoa have been shown to be apparently unaffected by concentrations of streptomycin from 0.1 to $0.8 \mathrm{~mm}$ and to continue to metabolize glucose in streptomycin-treated suspensions with the same endproducts as in untreated suspensions (Heald et al. 1952; Heald \& Oxford, 1953). This suggests their independence, for their carbohydrate metabolism, of commensal bacteria. The rumen oligotrich protozoa, however, appear to be wholly or partly dependent on bacteria. Most Entodinium species, apart from those already observed to be bacteria-feeders, die out within $24 \mathrm{hr}$. after streptomycin treatment. This might be expected, if it were assumed that they need bacteria for some of their metabolic processes, as these small and very 
actively motile cells could not survive for long without renewing their carbohydrate reserve and the only source of carbohydrate provided by the medium was rice starch.

Cells of $M$. medium are able to store considerable reserves of carbohydrate, and as they continue to live for 3 or 4 days after being treated with streptomycin they may well be able to draw on these reserves without the aid of bacteria. This assumes the probability that any commensal bacteria concerned in carbohydrate metabolism, if present, would have grown on the test medium used which was rich in yeast extract, starch and glucose. The importance of bacteria in the metabolism of $M$. medium, therefore, probably appears to be in the breakdown of ingested cellulose. It seems likely from the results of agar deep cultures that streptomycin destroys bacteria within the cells as well as in the medium. Symbiotic cellulolytic bacteria, if present in the cells, might reasonably be expected to grow in deep cultures of nutrient agar which contained cellobiose, since conditions below the top few $\mathrm{mm}$. are strictly anaerobic (Hungate, 1950).

The rapid toxic effect on rumen protozoa of streptomycin reported by d'Agostino Barbaro (1951) apparently contradicts the results given in the present paper; but this may be due to differences in the method of testing. It seems that she made no attempt to simulate conditions in which the protozoa would grow, as has been done in the present work, but simply incubated whole rumen contents partly diluted with distilled water, with the antibiotic, making counts at intervals.

There is no doubt that the large oligotrichs, e.g. M. medium, obtain their carbohydrate substrate mainly from cellulose, and that they lose the ability to utilize cellulose in the absence of bacteria. This would suggest that they rely on symbiotic cellulolytic bacteria and do not possess a cellulase of their own as reported by Hungate (1942) for other related oligotrichs. The starchlike polysaccharide which $M$. medium stores as a result of cellulose assimilation, can be extracted from the dried cultures by the method of Pucher, Leavenworth \& Vickery (1948), as was the holotrich starch (Masson \& Oxford, 1951). A yield of approximately $9 \%$ starch was obtained from the dried oligotrich protozoa fraction, separated from excess cellulose and bacteria by filtration through bolting silk, when a 3-day-old culture of $\boldsymbol{M}$. medium with an original total population of $\mathbf{2 8 9 , 0 0 0}$ cells was used.

It is known that the protozoa in the rumen are not essential to stall-fed sheep because it has been shown that when the protozoa are destroyed by starvation (Ferber, 1928) or by copper sulphate treatment (Becker, 1929) the sheep continue to live normally. It has been shown in the present paper that in some of their digestive processes the protozoa are aided by symbiotic bacteria. These may be similar to the free cellulolytic bacteria which will carry on the normal metabolic processes of the sheep rumen in the absence of protozoa (Hungate, 1942).

A way in which protozoa might be of importance to the ruminant host was originally suggested by Mangold (1929). This was the suggestion that protozoa, by converting starch and sugar to storage polysaccharide, would prevent or 
impede rapid bacterial attack on these fodder constituents. Since 1929 it has been shown that the products of bacterial metabolism of carbohydrates in the sheep rumen are mainly acetic, propionic and butyric acids. Heald \& Oxford (1953) showed that the rumen holotrich protozoa also yield these acids together with lactic acid, by fermentation of carbohydrates; but it is not yet known what are the fermentation products of the cellulose-ingesting oligotrich protozoa, either in the presence or absence of bacteria. Both oligotrich and holotrich protozoa can store enough reserve carbohydrate to survive for several days without other metabolizable carbohydrates, so that in the short time between feeds by the host ruminant, they could continue slowly to liberate carbohydrate degradation products, after the initial burst of bacterial carbohydrate metabolism had subsided.

The conclusion which can be reached is that, in accordance with previous suggestions (Mangold, 1929; Hungate, 1942), there is a true symbiotic relationship between the host animal and the protozoa. This applies to all groups of rumen protozoa and not merely to those which digest cellulose (Hungate, 1943). When considering the role of protozoa in the rumen, one must take into account the existence of a double symbiosis, involving both protozoa-ruminant and protozoa-bacteria relationships.

My sincere thanks are due to Dr A. E. Oxford for much helpful advice throughout this study.

\section{REFERENCES}

D'Agostino Barbaro, A. (1951). Sugli effetti del trattamento in vitro della fauna protozoaria del rumine degli erbivori con antibiotici e sulfamidici. Zootec. $e$ Vet. 6, 432.

BECKER, E. R. (1929). Methods for rendering the rumen and reticulum of ruminants free from their normal infusorial fauna. Proc. nat. Acad. Sci., Wash. 15, 435.

Bhatia, B. L. (1936). The Fauna of British India. Protozoa-Ciliophora. London: Taylor and Francis.

Crampton, E. W. \& Maynard, L. A. (1938). The relation of cellulose and lignin content to the nutritive value of animal feeds. J. Nutrit. 15, 383.

Dogres, V. A. (1927). Monographie der Familie Ophryoscolecidae. Arch. Protistenk. $59,1$.

Ferber, K. E. (1928). Die Zahl und Masse der Infusorien im Pansen und ihre Bedeutung für den Eiweissaufbau der Wiederkäuer. Z. Tierz. ZüichtBiol. 12, 31.

Heald, P. J., Oxford, A. E. \& Sugden, B. (1952). A convenient method for preparing massive suspensions of virtually bacteria free ciliate protozoa of the genera Isotricha and Dasytricha for manometric studies. Nature, Lond. 169, 1055.

Heald, P. J. \& Oxrord, A. E. (1953). Fermentation of soluble sugars by anaerobic holotrich ciliate protozoa of the genera Isotricha and Dasytricha. Biochem. J. $53,506$.

Hungate, R. E. (1942). The culture of Eudiplodinium neglectum with experiments on the digestion of cellulose. Biol. Bull., Wood's Hole, 83, 303.

Hungate, R. E. (1943). Further experiments on cellulose digestion by protozoa in the rumen of cattle. Biol. Bull., Wood's Hole, 84, 157.

Hungate, R. E. (1950). The anaerobic mesophilic cellulolytic bacteria. Bact. Rev. 14, 1. 
Journal of General Microbiology, Vol. 9, No. 1

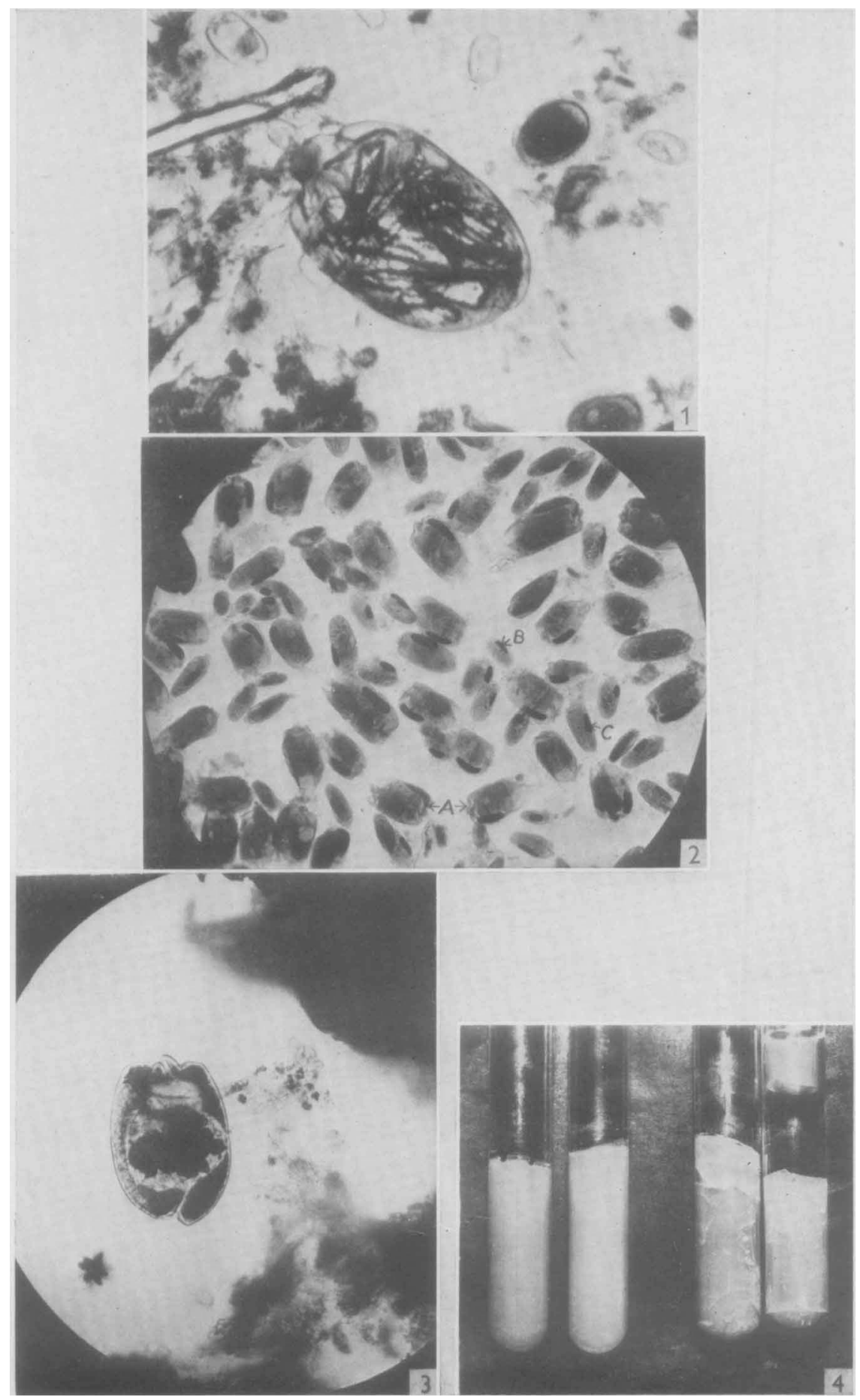

B. Sugden-Culture and metabolism of rumen oligotrichs. Plate 1 
Кмотн, M. (1928). Neue Versuche zur Züchtung der im Pansen von Wiederkäuern lebenden Ophryoscoleciden (Ciliata). Z. Parasitenk. 1, 262.

Kofom, C. A. \& MacLennan, R. F. (1932). Ciliates from Bos indicus Linn. II. A revision of Diplodinium Schuberg. Univ. Calif. Publ. Zool. 37, 53.

MacPherson, M. J. (1953). Isolation and identification of amylolytic streptococci from the rumen of sheep. J. Path. Bact. 66 (in the Press).

Mangoud, E. (1929). Handbuch der Ernährung und des Stoffwechsels der Landwirtschaftlichen Nutztiere. Zweiter Band, p. 156. Berlin: Julius Springer.

Margolin, S. (1930). Methods for the cultivation of cattle ciliates. Biol. Bull., Wood's Hole, 59, 301.

Masson, F. M. \& OxFond, A. E. (1951). The action of the ciliates of the sheep's rumen upon various water-soluble carbohydrates including polysaccharides. J. gen. Microbiol. 5, 664 .

OxFond, A. E. (1951). The conversion of certain soluble sugars to a glucosan by holotrich ciliates in the rumen of sheep. J. gen. Microbiol. 5, 83.

Phelps, A. (1947). A method of isolating from natural waters those protozoa which can live in pure culture. Anat. Rec. 99, 605.

Pucher, G. W., Leavenworth, C. S. \& Vickery, H. B. (1948). Determination of starch in plant tissues. Anal. Chem. 20, 850.

Pulvertaft, R. J. V. (1952). The effect of antibiotics on growing cultures of Bacterium coli. J. Path. Bact. 64, 75.

Sugden, B. \& Oxrord, A. E. (1952). Some cultural studies with holotrich ciliate protozoa of the sheep's rumen. J. gen. Microbiol. 7, 145.

Wasserman, R. H., Duncan, C. W., Churchild, E. S. \& Huffman, C. F. (1952). Effect of antibiotics on in vitro cellulose digestion by rumen micro-organisms. J. Dairy Sci. 35, 571.

WestPhal, A. (1934). Studien über Ophryoscoleciden in der Kultur. Z. Parasitenk. $7,71$.

\section{EXPLANATION OF PLATE}

Fig. 1. Ingestion of cellulose fibres (cotton-wool) by Metadinium medium. Partly crossed Nicols. $\times 180$.

Fig. 2. Variety of Entodinium spp. in rumen liquor from hay-fed sheep, including $E$. caudatum $(A)$, E. simplex $(B)$ and $E$. nanellum $(C)$. Haematoxylin. $\times 260$.

Fig. 3. Entodinium longinucleatum digesting rice starch grains. Stained with Lugol's iodine to show ingested starch concentrated in the 'gastric sac' and storage starch around the periphery. $\times \mathbf{4 5 0}$.

Fig. 4. Growth of bacteria in agar deeps after inoculation with protozoa from control (on right) and streptomycin-treated (on left) cultures. Note disruption of agar in control tubes due to gas-producing bacterial colonies. $\times \frac{1}{2}$.

(Received 26 January 1953) 